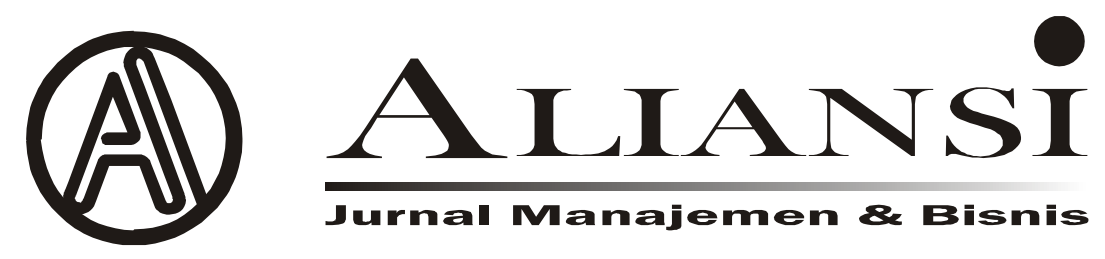

\title{
ANALISIS PENGARUH PROMOSI TERHADAPTINGKAT PENJUALAN PRODUK BESERTA PERAMALAN PENJUALANNYA
}

\author{
(STUDI KASUS PADA PT. ASKOTAMA INTI NUSANTARA) \\ Oleh : Sendianto \\ email : sendianto332@gmail.com
}

ABSTRACT

Promotion has an important role in marketing management in order to increase sales results because without promotion it is very difficult to convince buyers. Sales is an oral presentation by the company to one or several prospective buyers with the aim that the goods or services offered can be sold. The purpose of this research is to find out whether there is an analysis of the influence of promotion on the level of product sales and their sales forecasting at PT. Askotama Inti Nusantara. "The sampling technique used in this study the author uses the Random Sampling technique (Randomly on All Consumers) where each member of the population has an equal opportunity to be selected as a sample using the Slovin formula quoted by Sevilla in Husein Umar (2012)“The results obtained that partially and simultaneously there is a positive and significant influence between Promotions on Product Sales Levels and Sales Forecasting. "Keywords: Promotion and Product Sales Level and Sales Forecasting.

\section{PENDAHULUAN}

\section{Latar Belakang Masalah}

Promosi merupakan elemen yang penting dalam bauran pemasaran, dengan kegiatan promosi perusahaan dapat memperkenalkan suatu produk atau jasa kepada konsumen, dengan demikian konsumen akan mengetahui adanya suatu produk atau jasa. Fungsi promosi dalam bauran pemasaran adalah untuk mencapai tujuan komunikasi dengan para konsumen. Promosi berperan dalam menghasilkan penyampaian informasi yang baik kepada konsumen akan manfaat dan kelebihan suatu produk atau jasa, sehingga dapat mempengaruhi benak konsumen tersebut. Pada hakikatnya promosi adalah suatu bentuk komunikasi pemasaran. Yang dimaksud dengan komunikasi pemasaran adalah aktivitas pemasaran yang berusaha menyebarkan informasi, mempengaruhi/membujuk, dan/atau mengingatkan pasar sasaran atas perusahaan dan produknya agar bersedia menerima, membeli, dan loyal pada produk yang ditawarkan perusahan yang bersangkutan.

Sebagian orang menganggap bahwa promosi dan pemasaran mempunyai pengertian yang sama, padahal sebenarnya promosi hanya merupakan salah satu bagian dari kegiatan pemasaran. Walaupun promosi sering dihubungkan dengan penjualan tetapi kenyataannya promosi mempunyai arti yang lebih luas dari penjualan karena penjualan hanya berhubungan dengan pertukaran hak milik yang dilakukan oleh tenaga penjual, sedangkan promosi adalah setiap aktivitas yang ditujukan untuk memberitahukan, membujuk atau mempengaruhi konsumen untuk tetap menggunakan produk yang dihasilkan perusahaan tersebut. Promosi meliputi kegiatan perencanaan, implementasi dan pengendalian komunikasi dari suatu organisasi kepada konsumen serta sasaran lainya. Promosi merupakan kumpulan aktivitas yang memberitahu kebaikan produk dan membujuk pelanggan sasaran untuk membelinya.

Promosi dapat dikategorikan sebagai komponen dalam campuran pemasaran yang menekankan teknik yang berkesan untuk menjual produk. Promosi sangat berperan untuk meningkatkan penjualan produk dan jasa yang dihasilkan perusahaan, promosi juga dapat mempengaruhi nilai jual produk dan jasa ke konsumen dan yang paling penting dalam mempromosikan dan menawarkan sebuah produk dan jasa adalah inovasi yang berkelanjutan untuk menghindari kejenuhan konsumen, begitu juga dengan inovasi produk dan jasa yang bermanfaat untuk mengembangkan produk dan jasa yang ditawarkan (Kotler, 2014). Dimana penilai promosi itu melibatkan emosi atau perasaan tertentu 
dalam diri konsumen terhadap promosi tersebut (disebut tanggapan efektif), tanggapan konsumen ini merupakan tahap penerimaan terhadap kegiatan promosi yang dilakukan perusahaan.

Pada era modern seperti saat ini persaingan dunia pemasaran produk atau jasa sudah merupakan fenomena yang tak terhindarkan, yang ditandai dengan perubahan-perubahan yang serba cepat khususnya penggunaan teknologi yang lebih canggih atau media cetak, media informasi, dan lain sebagainya yang serba modern untuk mempromosikan produk dan jasanya. Dengan promosi yang terencana dengan baik dan teratur dapat memperkecil biaya dan bisa mendapatkan laba optimal (sesuai dengan prinsip ekonomi). Sudah barang tentu melalui promosi diharapkan bisa meningkatkan minat konsumen serta meningkatkan penghasilan kalaupun tidak bisa, paling tidak dapat mempertahankan konsumen yang telah dicapai. Tetapi sebaliknya kalau promosi tidak berhasil hanya akan menambah pengeluaran sehingga perusahaan mengalami kerugian.

Berhasil tidaknya suatu promosi sebenarnya tergantung dari perusahaan itu sendiri, apakah dalam menugaskan karyawan sudah sesuai dengan bidangnya atau belum. Bahkan mungkin keliru dalam memilih pelaksanaan promosinya dengan produk yang akan dipublikasikannya. Usaha promosi tidak dapat sendiri melainkan bagian dari kebijaksanaan pemasaran yang terpadu, sehingga strategi dan pelaksanaannya harus pula terpadu dengan kebijakan pemasaran yang lain. Promosi yang dilakukan perusahaan masih belum terlihat berjalan optimal dan masih diperlukan pembenahan oleh semuah pihak agar kedepannya lebih baik dan sesuai sebagaimana harapkan pimpinan perusahaan.

\section{Perumusan Masalah}

Berdasarkan permasalahan seperti yang diuraikan dalam latar belakang masalah, maka perumusan masalah dalam penelitian ini dapat dirumuskan sebagai berikut : Apakah ada pengaruh Promosi terhadap Tingkat Penjualan Produk Beserta Peramalan Penjualannya Pada PT. Askotama Inti Nusantara ?

\section{Tujuan Penelitian}

Berdasarkan pada perumusan masalah tersebut di atas, maka tujuan yang ingin dicapai dalam penelitian ini adalah menjawab perumusan masalah dalam penelitian ini adalah : Untuk mengetahui apakah ada pengaruh Promosi terhadap Tingkat Penjualan Produk Beserta Peramalan Penjualannya Pada PT. Askotama Inti Nusantara.

\section{TINJAUAN PUSTAKA Pengertian Promosi}

Pengertian promosi adalah memberitahukan pembeli atas produk dan jasa yang bersangkutan di pasar, serta meyakinkan mereka bahwa barang atau jasa tersebut dapat memberikan kepuasan kepada konsumen sesuai dengan yang mereka inginkan. Karena itu promosi mempunyai peranan penting dalam manajemen pemasaran guna meningkatkan hasil penjualan karena tanpa adanya promosi sangatlah sulit untuk dapat meyakinkan pembeli. Kegiatan promosi yang dilakukan oleh suatu organisasi merupakan kombinasi yang terdapat dari unsur-unsur atau peralatan promosi yang mencerminkan suatu kebijaksanaan-kebijaksanaan pelaksanaan promosi dari organisasi tersebut. Setelah produk dikenal dan digemari oleh konsumen, maka produk mencapai tingkat pertumbuhan (growth), dalam masa ini organisasi mengalami suatu kenaikan jumlah penjualan yang sangat cepat. Menurut pendapat para ahli diantaranya adalah menurut Basu Swastha DH dan Irawan (2010 : 549) mengemukakan promosi bahwa : "Promosi adalah suatu arus informasi atau persuasi satu arah yang dibuat untuk mengarahkan seseorang atau organisasi kepada tindakan yang menciptakan pertukaran dalam pemasaran".

Menurut Philip Kotler (2014 ; 20), mengemukakan pengertian promosi sebagai berikut: "Promosi adalah kegiatan yang menunjuk kepada berbagai aktivitas yang dilakukan oleh perusahaan untuk mengkomunikasikan kebaikan produknya dan membujuk beberapa para konsumen sasaran untuk membeli"

Sedangkan menurut Sofyan Assauri, (2014 : 87), mengemukakan pengertian promosi bahwa :

"Promosi merupakan konsep pemasaran dan suatu alat dari bauran pemasaran yang dirancang untuk memperagakan nama dan kegiatan badan yang dipromosikan dihadapan konsumen yang sekarang ada dan yang pontensial".

Selanjutnya menurut pendapat William J. Stanton (2012 : 67) mengemukakan pengertian promosi adalah sebagai bahwa : 
"Promosi adalah merupakan pemakaian beberapa cara untuk menyampaikan sesuatu berita, mempengaruhi para konsumen untuk merubah sikapnya, memberikan penerangan dan sebagainya yang dapat membantu meng-"create" suatu temuan dan membantu terlaksananya suatu penjualan".

Dalam melakukan promosi diperlukan serangkaian bentuk serta kombinasi promosi yang paling sesuai dengan keadaan perusahaan yang bersangkutan. Bentuk-bentuk promosi tersebut yaitu : Bentuk-bentuk promosi tersebut yaitu :

\section{Periklanan (Advertising)}

Periklanan atau advertising merupakan salah satu alat promosi yang digunakan dalam pelaksanaan komunikasi yang persuasif oleh perusahaan kepada pembeli potensial pada segmen pasar sasaran yang dituju. Guna mendukung pemikiran penulis tentang pengertian periklanan, akan penulis sajikan beberapa pendapat dari para ahli sebagai berikut:

Menurut Basu Swastha DH (2010 : 223) dalam bukunya Pengantar Bisnis Modern, mengemukakan : "Periklanan adalah suatu komunikasi non-individu, dengan sejumlah biaya, melalui berbagai media dilakukan oleh perusahaan, lembaga-lembaga non laba serta individu-individu".

Selanjutnya menurut pendapat Philip Kotler (2014 : 220) mengemukakan bahwa : "Periklanan terdiri dari bentuk-bentuk komunikasi non-pribadi (non-personal) yang diselenggarakan melalui media bayaran dengan sponsor yang nyata".

\section{Promosi Penjualan (Sales Promotion)}

Merupakan kegiatan promosi yang dilakukan untuk menggugah atau menstimulir pembeli atau konsumen bisa juga dikatakan suatu usaha penjualan khusus. Promosi penjualan pada kenyataannya paling sering digunakan untuk pembeli dengan berdasarkan objek yang dituju yaitu :

\section{a) Consumer Promotion}

Yaitu promosi yang ditujukan bagi konsumen, tujuan tersebut antara lain untuk lebih banyak menggunakan produk, untuk membeli produk dalam unit yang lebih besar, mencoba merek yang dipromosikan dan untuk bersaing dengan merek lainnya.

\section{b) Trade Promotion}

Yaitu promosi yang ditujukan bagi pengecer, tujuannya adalah untuk membujuk pengecer agar menjual barang produk baru dan menimbun barang-barang yang dipromosikan, mengimbangi promosi para pesaing.

c) Sales Force Promotion

Yaitu promosi yang ditujukan bagi wiraniaga, tujuannya adalah untuk memberi dukungan atas produk baru, untuk merangsang mereka mencari pelanggan baru dan mendorong penjualan di musim sepi.

\section{Penjualan Perorangan (Personal Selling)}

Penjualan perorangan adalah penyajian secara lisan oleh perusahaan kepada satu atau beberapa calon pembeli dengan tujuan agar barang atau jasa yang ditawarkan dapat terjual dan menimbulkan hubungan timbal balik dalam rangka membuat, mengubah, menggunakan atau membina hubungan komunikasi antara produsen dengan konsumen.

Untuk dapat melakukan personal selling, seorang tenaga penjual harus bisa meyakinkan konsumen terhadap mutu atau kualitas produknya lebih baik dibanding dengan produk pesaing, harus berkepribadian yang menarik dan menyenangkan, mempunyai kemampuan untuk bekerja keras serta mengenal psikologi praktis.

\section{Publisitas (Publicity)}

Publisitas merupakan stimulasi permintaan akan suatu barang atau jasa, dengan cara membuat berita yang mempunyai arti komersial. Dapat dikatakan bahwa publisitas merupakan rangsangan terhadap permintaan suatu produk dengan cara menyusun berita yang menarik dalam suatu media publisitas. Ada beberapa kelebihan cara promosi dengan publisitas yaitu :

a) Konsumen cenderung lebih percaya, karena model promosi seperti ini tidak dalam bentuk iklan melainkan suatu berita.

b) Keengganan konsumen untuk bertemu langsung dengan salesman.

c) Ada kemampuan publisitas untuk dibuat menjadi lebih menarik, sehingga produk atau perusahaan dapat lebih dikenal oleh konsumen. 
Di dalam istilah pemasaran, kombinasi dari unsurunsur promosi ini disebut Bauran Promosi (Promotion Mix). Promosi menurut Philif Kotler (2014 : 142) ini terdiri dari :

a. Periklanan (Advertising)

Periklanan adalah suatu bentuk penyajian dan promosi dari suatu ide (gagasan), barang atau jasa dibiayai oleh suatu organisasi atau sponsor tertentu. Sedangkan media yang sering digunakan adalah Radio, Televisi, Surat Kabar, Majalah dan Bilboard.

b. Penjualan Pribadi (Personal Selling)

Penjualan pribadi merupakan suatu penyajian secara lisan dalam suatu pembicaraan dengan seseorang atau lebih dengan tujuan agar calon pembeli segera merealisir pembelian terhadap produk yang ditawarkan.

c. Publisitas (Publicity)

Publisitas merupakan suatu usaha yang dilakukan untuk menimbulkan rangsangan permintaan terhadap suatu produk secara Non Personal dengan membuat berita komersiil yang menarik. Media yang sering digunakan adalah Televisi, Radio, Surat Kabar dan Majalah.

d. Promosi Penjualan (Sales Promotion)

Promosi penjualan adalah segala kegiatan pemasaran selain periklanan, penjualan pribadi, publisitas yang merangsang untuk konsumen membeli.

Promosi merupakan salah satu variabel dari bauran pemasaran (marketing communication mix), yaitu suatu perpaduan antara periklanan, penjualan personal dan publisitas. Agar promosi yang dilakukan oleh perusahaan efektif, perlu ditentukan terlebih dahulu peralatan atau unsur promosi yang digunakan.

\section{Pengertian Penjualan}

Menurut Tjiptono (2008 : 215), “penjualan adalah pengalihan atau pemindahan hak kepemilikan atas barang atau jasa dari satu pihak kepihak lain disertai dengan penyerahan imbalan dari pihak penerima barang atau jasa sebagai timbal balik atas penyerahan tersebut". Penjualan merupakan aktivitas utama yang dilakukan oleh hampir semua badan usaha, karena hasil dari penjualan tersebut merupakan bagian dari kelangsungan hidup perusahaan itu sendiri. Penjualan merupakan suatu alat yang menghasilkan pendapatan baik berupa penerimaan kas maupun piutang usaha. Oleh karena itu semua perusahaan harus pandai dalam menjalankan kegiatan penjualanproduknya dan juga yang perlu diperhatikan adalah sasaran penjualan tersebut.
Penjualan merupakan salah satu fungsi pemasaran yang sangat penting dan menentukan bagi perusahaan dalam mencapai tujuan perusahaan yaitu memperoleh laba untuk menjaga kelangsungan hidup perusahaan. Sebenarnya pengertian penjualan sangat luas, beberapa para ahli mengemukakan tentang definisi penjualan antara lain : Menurut Moekijat (2000:488) menyatakan bahwa: "Selling : melakukan penjualan adalah suatu kegiatan yang ditujukan untuk mencari pembeli, mempengaruhi dan memberikan petunjuk agar pembeli dapat menyesuaikan kebutuhannya dengan produk yang ditawarkan serta mengadakan perjanjian mengenai harga yang menguntungkan bagi kedua belah pihak"

Menurut Basu Swastha (2008:8), adalah "Menjual adalah ilmu dan seni mempengaruhi pribadi yang dilakukan oleh penjual, untuk mengajak orang lain bersedia membeli barang atau jasa yang ditawarkan" Menurut Philip Kotler (2008:8) pengertian penjualan adalah: "Penjualan adalah proses sosial manajerial dimana individu dan kelompok mendapatkan apa yang mereka butuhkan dan inginkan, menciptakan, menawarkan, dan mempertukarkan produk yang bernilai dengan pihak lain" Menurut Kusnadi (2009:19) yang menjelaskan bahwa "Penjualan (sales) adalah sejumlah uang yang dibebankan kepada pembeli atas barang atau jasa yang dijual". Menurut Soemarso (2005:253) menyatakan bahwa "Penjualan bersih (net sales) adalah penjualan dikurangi dengan pengembalian, pengurangan harga biaya transpor yang dibayar untuk langganan dan potongan penjualan yang diambil". Dari penjelasan di atas dapat dipahami bahwa penjualan adalah kegiatan yang terpadu untuk mengembangkan rencana-rencana strategis yang diarahkan kepada usaha pemuasan kebutuhan serta keinginan pembeli/konsumen, guna untuk mendapatkan penjualan yang menghasilkan laba atau keuntungan. Dan juga dapat disimpulkan bahwa penjualan merupakan suatu kegiatan transaksi yang dilakukan oleh 2 (dua) belah pihak/lebih dengan menggunakan alat pembayaran yang sah.

Jenis Penjualan Menurut Basu Swastha (2008:48), terdapat beberapa jenis penjualan yang biasa dikenal dalam masyarakat diantaranya adalah:

1. Trade Selling

2. Missionary Selling

3. Technical Selling

4. New Businies Selling

5. Responsive Selling"

Adapun penjelasan dari klasifikasi di atas yang dikemukakan oleh Basu Swatha, yaitu: 
1. Trade Selling, penjualan yang terjadi bilamana produsen dan pedagang besar mempersilahkan pengecer untuk berusaha memperbaiki distribusi produk mereka,. Hal ini melibatkan para penyalur dengan kegiatan promosi, peragaan, persediaan dan produk baru, jadi titik beratnya adalah para penjualan melalui penyalur bukan pada penjualan ke pembeli akhir.

2. Missionary Selling, penjualan berusaha ditingkatkan dengan mendorong pembeli untuk membeli barang dari penyalur perusahaan.

3. Technical Selling, berusaha meningkatkan penjualan dengan pemberian saran dan nasihat kepada pembeli akhir dari barang dan jasa.

4. New Business Selling, berusaha membuka transaksi baru dengan membuat calon pembeli menjadi pembeli seperti halnya yang dilakukan perusahaan asuransi.

5. Responsive Selling, setiap tenaga penjual diharapkan dapat memberikan reaksi terhadap permintaan pembeli melalui route driving and retaining. Jenis penjualan ini tidak akan menciptakan penjualan yang besar, namun terjalin hubungan pelanggan yang baik yang menjurus pada pembelian ulang.

Bentuk Penjualan selain itu terdapat bentukbentuk transaksi penjualan yang dapat diklasifikasikan sebagai berikut :

a) Penjualan secara tunai Adalah penjualan yang bersifat "cash and carry" dimana penjualan setelah terdapat kesepakatan harga antara penjual dengan pembeli, maka pembeli menyerahkan pembayaran secara kontan dan biasa langsung dimiliki oleh pembeli.

b) Penjualan kredit Adalah penjualan non cash dengan tenggang waktu rata-rata diatas 1 bulan.

c) Penjualan secara tender Adalah penjualan yang dilaksanakan melalui prosedur tender untuk memenuhi permintaan pihak pembeli yang membuka tender.

d) Penjualan ekspor Adalah penjualan yang dilaksanakan dengan pihak pembeli luar negeri yang mengimpor barang yang biasanya menggunakan fasilitas letter of credit (LC).

e) Penjualan secara konsiyasi Adalah penjualan barang secara "Titipan" kepada pembeli yang juga sebagai penjual apabila barang tersebut tidak terjual maka akan dikembalikan pada penjual. f) Penjualan secara grosir Adalah penjualan yang tidak langsung kepada pembeli, tetapi melalui pedagang perantara yang menjadi perantara pabrik/importir dengan pedagang eceran.

Faktor-Faktor Yang Mempengaruhi Penjualan Dalam praktek, kegiatan penjualan ini dipengaruhi oleh beberapa faktor yaitu :

1. Kondisi dan Kemampuan Penjual Disini penjual harus dapat meyakinkan pembeli agar berhasil mencapai sasaran penjualan yang diharapkan untuk maksud tertentu, penjual harus memahami beberapa masalah penting yang sangat berkaitan yaitu :
a) Jenis dan karakteristik barang yang ditawarkan
b) Harga Produk
c) Syarat penjualan seperti pembayaran, pengantaran, garansi, dan sebagainya.

2. Kondisi Pasar Hal yang harus diperhatikan pada kondisi pasar antara lain:

a. Jenis pasarnya, apakah pasar konsumen, pasar industri, pasar pemerintah atau pasar Internasional

b. Kelompok pembeli dan segmen pasarnya

c. Daya beli

d. Frekuensi pembeliannya

e. Keinginan dan kebutuhan

Dalam kegiatan pemasaran yang sangat kompleks dan saling berkaitan yang satu dengan yang lainnya, seperti promosi dan penjualan hendaknya dikelola dengan baik untuk mencapai tujuan perusahaan, yaitu laba. Promosi berfungsi untuk meningkatkan penjualan juga sebagai strategi untuk menjangkau pembeli untuk melakukan pertukaran. Sedangkan penjualan adalah pemindahan barang dan jasa yang dilakukan oleh penjual. Pada umumnya perusahaan yang ingin mempercepat proses peningkatan penjualan akan melakukan untuk mengadakan kegiatan promosi melalui iklan, personal selling, dan publisitas. Apabila penjualan dirasakan cukup besar sesuai dengan yang diinginkan serta cukup mantap, maka umumnya perusahaan menurunkan kegiatan promosi atau sekedar mempertahankannya. Meskipun demikian seringkali perusahaan dalam menurunkan kegiatan promosi diikuti pula oleh penurunan penjualan. Hal ini disebabkan oleh karena beberapa kemungkinan, misalnya penurunan promosi

Dari penjelasan mengenai penjualan, penjualan selalu dihubungkan dengan istilah volume penjualan. Penjualan merupakan salah satu bentuk baku dari kinerja perusahaan. 
Berhasil tidaknya suatu perusahaan dapat dilihat dari kondisi volume penjualan secara keseluruhan. Volume penjualan disini juga sebagai salah satu bentuk kinerja perusahaan dalam menjalankan kegiatan usahanya, tujuan utama dari perusahaan adalah untuk memperoleh keuntungan. Salah satunya ialah dengan meningkatkan volume penjualan yang dihasilkan oleh perusahaan.

Penjualan menurut pendapat yang dikemukakan oleh John Downes dan Jordan Elliot Goodman yang dikutip oleh Susanto Budidharmo (2010 : 646), yaitu : "Penjualan adalah total penjualan yang didapat dari komoditas yang diperdagangkan dalam suatu masa tertentu". Menurut Winardi (2001:359), definisi volume penjualan adalah sebagai berikut: "Volume penjualan adalah hasil penjualan yang dinyatakan dalam bentuk kualitatif, fiskal atau volume". Sedangkan menurut Swastha (2010:141), menyatakan bahwa: "Volume penjualan merupakan penjualan bersih dari laporan laba perusahaan. Penjualan bersih diperoleh melalui hasil penjualan seluruh produk (produk lini) selama jangka tertentu, dan hasil penjualan yang diperoleh dari market share (pangsa pasar) yang merupakan penjualan potensial, yang dapat terdiri dari kelompok teritorial dan kelompok pembeli saham jangka waktu tertentu".

Berdasarkan definisi diatas dapat disimpulkan bahwa penjualan merupakan hasil dari kegiatan penjualan yang dilakukan pihak produsen dalam hal ini adalah perusahaan ketangan konsumen dalam usahanya mencapai sasaran yaitu memaksimalkan laba untuk periode yang ditentukan.

\section{METODE PENELITIAN}

\section{Populasi}

Populasi adalah jumlah keseluruhan orang yang akan diteliti. Menurut pendapat Singarimbun Masri, (2015 : 97) mengemukakan pengertian populasi bahwa :

"Populasi adalah keseluruhan subyek penelitian. Apabila seseorang ingin meneliti semua elemen yang ada dalam wilayah penelitian, maka penelitiannya merupakan penelitian populasi atau studi populasi atau studi sensus, yaitu mendata keseluruhan populasi yang ada".

Sedangkan menurut pendapat Mohamad Nazir (2010 : 27) mengemukakan pengertian populasi bahwa : "Populasi adalah unsur atau unit elementer adalah suatu obyek dimana suatu penelitian akan dilakukan pengukuran-pengukuran, kumpulankumpulan dari unit-unit elementer tersebut disebut "populasi”".
Adapun populasi selama \pm 3 bulan ada 341 orang konsumen pada PT. Askotama Inti Nusantara..

\section{Sampel}

Teknik pengambilan sampel yang dipakai dalam penentuan besarnya sampel dapat digunakan model rumus Slovin yang dikutip Sevilla dalam Husein Umar (2012: 78, yaitu :

$$
\begin{array}{lll}
\mathrm{n}= & \text { jumlah sampel } \\
\mathrm{N}= & \text { jumlah populasi } \\
\mathrm{e}= & \begin{array}{l}
\text { Error }(\% \text { yang dapat ditoleransi terhadap } \\
\text { ketidaktepatan penggunaan sampel } \\
\text { sebagai pengganti populasi) }
\end{array}
\end{array}
$$

Dalam hal ini penulis menggunakan error sebesar $10 \%$ sehingga besarnya sampel dapat dihitung sebagai berikut :

$$
\begin{aligned}
& \mathrm{n}=\frac{\mathrm{N}}{1+\mathrm{N}(\mathrm{e})^{2}} \\
& =\frac{341}{1+341(0,10)^{2}} \\
& =77 \text { orang sampel } \\
& \mathrm{N}
\end{aligned}
$$

Sehingga sampel yang diambil dalam penelitian adalah sebanyak 77 orang konsumen sebagai sampel.

\section{Instrumen/Alat Pengumpulan Data}

Menurut Suharsimi Arikunto (2014:225), Teknik pengumpulan data merupakan suatu usaha sadar untuk mengumpulkan data yang dilaksanakan secara sistematis dengan prosedur yang standar. Teknik pengumpulan data yang digunakan dalam penelitian ini adalah: Kuesioner (Angket).

Kuesioner adalah sejumlah pertanyaan tertulis yang digunakan untuk memperoleh informasi dari responden dalam arti laporan tentang pribadinya atau hal-hal yang diketahui. Menurut Suharsimi Arikunto (2014 : 140) Metode ini digunakan untuk mengumpulkan data dari responden mengenai promosi dan Tingkat Penjualan Produk Beserta Peramalan Penjualannya. Menurut Sonny Harsono (2010 : 290) mengemukakan pengertian kuesioner adalah :

"Kuesioner yaitu suatu teknik pengumpulan data dengan menggunakan seperangkat pertanyaan yang disusun untuk diajukan kepada para karyawan. 
Kuesioner ini dimaksudkan untuk memperoleh data secara tertulis dari para karyawan untuk ditetapkan sebagai sampel".

Jenis instrumen yang digunakan dalam penelitian ini berupa skala yaitu merupakan kumpulan dari pernyataan atau pertanyaan yang pengisiannya oleh responden dilakukan dengan memberikan tanda centang (") pada tempat yang sudah disediakan dengan alternatif jawaban yang disediakan merupakan sesuatu yang berjenjang.

Untuk mengetahui distribusi frekuensi masingmasing variabel yang pengumpulan datanya menggunakan keusioner (angket), setiap indikator dari data yang dikumpulkan terlebih dahulu diklasifikasikan dan diberi skor atau nilai yaitu:

Tabel 1

Pilihan Jawaban

\begin{tabular}{|c|l|c|c|}
\hline No. & \multicolumn{1}{|c|}{ Jawabannya } & Disingkat & Bobot \\
\hline 1 & Sangat Tidak Setuju & STS & 1 \\
\hline 2 & Tidak Setuju & TS & 2 \\
\hline 3 & Ragu-Ragu & RR & 3 \\
\hline 4 & Setuju & S & 4 \\
\hline 5 & Sangat Setuju & SS & 5 \\
\hline
\end{tabular}

Sumber : Sugiyono, 2016.

\section{Tehnik Analisis Data}

Uji Validitas, Adapun teknik korelasi yang diterapkan dalam penelitian ini adalah teknik product moment correlation. Adapun rumus korelasi Product Moment menurut Sugiyono, (2016 : 182), untuk mencari nilai $r_{\text {hitung }}$ atau validitas sebagai berikut:

$$
\mathbf{r}_{\mathrm{xy}}=\frac{n \cdot \Sigma X Y-\Sigma X \cdot \Sigma Y}{\sqrt{n\left(\Sigma X^{2}\right)-(\Sigma X)^{2}} \cdot \sqrt{n \cdot\left(\Sigma Y^{2}\right)-(\Sigma Y)^{2}}}
$$

\section{Dimana :}

$$
\begin{aligned}
& \mathrm{r}_{\mathrm{xy}}=\text { Koefisien Korelasi antara } \mathrm{X} \text { dan } \mathrm{Y} \\
& \sum \mathrm{XY}=\text { Jumlah perkalian antara } \mathrm{X} \text { dan } \mathrm{Y} \\
& \sum \mathrm{X}^{2}=\text { Jumlah kuadrat } \mathrm{X} \\
& \sum \mathrm{Y}^{2}=\text { Jumlah kuadrat } \mathrm{Y} \\
& \mathrm{n} \quad=\text { Jumlah Sampel (Banyaknya Data). }
\end{aligned}
$$

Item-item pertanyaan di dalam angket dikatakan valid apabila nilai $r_{\text {hitung }}>$ dari $r_{\text {tabel }}$, sedangkan apabila nilai $r_{\text {hitung }}<$ dari $r_{\text {tabel }}$ maka item-item pertanyaan di dalam angket dikatakan tidak valid (Sugiyono, 2016:182).

Uji Reliabilitas, diukur dengan menggunakan metode cronbach alpha. Rumus Cronbach alpha: Adapun rumus untuk mencari nilai reliabilitas menurut Sugiyono, (2016: 122) sebagai berikut :

$$
\mathrm{r}_{11}=\left[\frac{k}{k-1}\right]\left[1 \frac{\Sigma a_{b}^{2}}{a_{t}^{2}}\right]
$$

\section{Keterangan :}

$\mathrm{r}_{11}=$ reliabilitas instrumen

$\mathrm{k}=$ banyaknya butir pertanyaan atau banyaknya soal

$\sum \alpha_{b}^{2}=$ jumlah varianes butir

$\alpha_{t}^{2}=$ varians total.

Suatu kuesioner dinyatakan reliabel apabila nilai $r_{\text {hitung }}$ lebih besar daripada nilai $r_{\text {tabel }}$ dengan taraf signifikan 5\%.

a. Uji t

Uji t dilakukan untuk mengetahui pengaruh signifikan secara parsial antara variabel independen terhadap variabel dependen. Nilai t test dapat diketahui dari nilai sig pada tabel Coefficientsa dalam output regression SPSS Versi 24 for windows.

\section{ANALISA DAN PEMBAHASAN}

Uji Validitas dan Reliabilitas Data Hasil Angket a. Variabel Promosi (X)

Untuk dapat mengetahui hasil analisis dari variabel Promosi (X) menggunakan Komputer program Statistical Package for Social Sciences (SPSS) Versi 24 for Windows, data variabel Promosi (X) yang merupakan data ordinal dari sampel berjumlah 10 Try Out $(\mathrm{N}=10)$ dengan jumlah soal ada 10 pertanyaan adalah :

Tabel 2

PERBANDINGAN HASIL $r_{\text {hitung }}$ dengan $r_{\text {tabel }}$ VARIABEL PROMOSI $(\mathrm{X})$

\begin{tabular}{|c|c|c|c|}
\hline \multirow{2}{*}{ Pertanyaan } & \multicolumn{3}{|c|}{ PROMOSI (X) } \\
\cline { 2 - 4 } & $\mathbf{r}_{\text {hitung }}$ & $\mathbf{r}_{\text {tabel }}$ & Keterangan \\
\hline 1 & 0,857 & 0,666 & Valid \\
2 & 0,876 & 0,666 & Valid \\
3 & 0,966 & 0,666 & Valid \\
4 & 0,851 & 0,666 & Valid \\
5 & 0,805 & 0,666 & Valid \\
6 & 0,942 & 0,666 & Valid \\
7 & 0,836 & 0,666 & Valid \\
8 & 0,921 & 0,666 & Valid \\
9 & 0,869 & 0,666 & Valid \\
10 & 0,909 & 0,666 & Valid \\
\hline
\end{tabular}

Sumber : Data diolah SPSS

Uji Reliabilitas variabel Promosi (X) dengan nilai $r_{\text {tabel }} 0,666$ sedangkan nilai Alpha 0,975 sehingga dapat disimpulkan bahwa Alpha positif dan lebih besar atau $0,975>0,666$ maka instrumen penelitian variabel Promosi (X) adalah Reliabel. 
Untuk lebih jelas lihat tabel berikut ini.

Tabel 3

UJI RELIABILITAS VARIABEL PROMOSI (X)

Reliability Statistics

\begin{tabular}{|c|cc|}
\hline \multicolumn{2}{|c|}{$\begin{array}{c}\text { Cronbach's } \\
\text { Alpha }\end{array}$} & N of Items \\
\hline & .975 & 10 \\
\hline
\end{tabular}

Sumber : Data diolah SPSS

\section{c. Variabel Tingkat Penjualan Produk Beserta Peramalan Penjualannya (Y)}

Untuk mengetahui hasil analisis dari variabel Tingkat Penjualan Produk Beserta Peramalan Penjualannya (Y) menggunakan Komputer program Statistical Package for Social Sciences (SPSS) Versi 24 for Windows input data variabel Tingkat Penjualan Produk Beserta Peramalan Penjualannya yang merupakan data ordinal dari sampel berjumlah 10 Try Out $(\mathrm{N}=10)$ dengan soal ada 10 pertanyaan sebagai berikut :

\section{Tabel 4}

PERBANDINGAN HASIL $r_{\text {hitung }}$ dengan $r_{\text {tabel }}$ VARIABEL TINGKAT PENJUALAN PRODUK BESERTA PERAMALAN PENJUALANNYA

$$
\text { (Y) }
$$

\begin{tabular}{|c|c|c|c|}
\hline \multirow{3}{*}{ Pertanyaan } & \multicolumn{3}{|c|}{$\begin{array}{c}\text { TINGKAT PENJUALAN PRODUK } \\
\text { BESERTA PERAMALAN } \\
\text { PENJUALANNYA (Y) }\end{array}$} \\
\cline { 2 - 4 } & $\mathbf{r}_{\text {hitung }}$ & $\mathbf{r}_{\text {tabel }}$ & Keterangan \\
\hline 1 & 0,800 & 0,666 & Valid \\
2 & 0,688 & 0,666 & Valid \\
3 & 0,870 & 0,666 & Valid \\
4 & 0,808 & 0,666 & Valid \\
5 & 0,854 & 0,666 & Valid \\
6 & 0,896 & 0,666 & Valid \\
7 & 0,974 & 0,666 & Valid \\
8 & 0,923 & 0,666 & Valid \\
9 & 0,764 & 0,666 & Valid \\
10 & 0,974 & 0,666 & Valid \\
\hline
\end{tabular}

Sumber : Data diolah SPSS

Uji Reliabilitas variabel Tingkat Penjualan Produk Beserta Peramalan Penjualannya (Y) dengan nilai $\mathrm{r}_{\text {tabel }} 0,666$, sedangkan pada nilai Alpha sebesar 0,960 sehingga dapat disimpulkan bahwa $\mathrm{r}_{\text {Alpha }}$ positif dan lebih besar atau 0,960>0,666 maka dengan demikian instrumen penelitian variabel Tingkat Penjualan Produk Beserta Peramalan Penjualannya (Y) adalah Reliabel. Untuk jelas lihat tabel berikut ini.
Tabel 5

Uji Relliabilitas

Variabel Tingkat Penjualan Produk BESERTA PERAMALAN PENJUALANNYA

(Y)

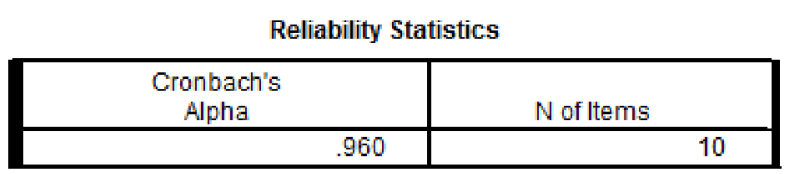

Sumber : Data diolah SPSS

\section{Analisis Koefisien Korelasi}

Hasil Analisis Korelasi Pasrial adalah salah satu metode statistik yang digunakan untuk mengetahui tingkat atau besarnya Pengaruh Variabel Promosi (X) terhadap variabel Tingkat Penjualan Produk Beserta Peramalan Penjualannya (Y) dapat dilihat pada tabel 6 berikut ini.

Tabel 6

HASIL ANALISIS KORELASI

Model Summary ${ }^{b}$

\begin{tabular}{|c|c|c|c|c|c|}
\hline Model & $\mathrm{R}$ & RSquare & $\begin{array}{l}\text { Adjusted R } \\
\text { Square }\end{array}$ & $\begin{array}{l}\text { Std. Error of the } \\
\text { Estimate }\end{array}$ & $\begin{array}{l}\text { Durbin- } \\
\text { Watson }\end{array}$ \\
\hline 1 & $.818^{\mathrm{a}}$ & .669 & .665 & 5.34791 & 2686 \\
\hline
\end{tabular}

Sumber : Data diolah SPSS

\section{Analisis Regresi Linear Sederhana}

Hasil analisis regresi linear berganda dengan menggunakan Komputer program Statistical Package for Social Sciences (SPSS) Versi 24 for Windows yakni diperoleh nilai adalah sebagai berikut:

Tabel 7

analisis regresi linear berganda

\begin{tabular}{|c|c|c|c|c|c|c|}
\hline \multicolumn{7}{|c|}{ Coefficients $^{\mathrm{a}}$} \\
\hline \multirow{2}{*}{\multicolumn{2}{|c|}{ Model }} & \multicolumn{2}{|c|}{$\begin{array}{c}\text { Unstandardized } \\
\text { Coefficients }\end{array}$} & $\begin{array}{c}\text { Standardized } \\
\text { Coefficients } \\
\end{array}$ & \multirow[b]{2}{*}{$\mathrm{t}$} & \multirow[b]{2}{*}{ Sig. } \\
\hline & & $\mathrm{B}$ & Std. Error & Beta & & \\
\hline 1 & (Constant) & 7.702 & 2.048 & & 7.180 & .000 \\
\hline & Promosi Jasa (X) & .709 & .058 & .818 & 12.316 & .000 \\
\hline
\end{tabular}

a. Dependent Variable: Kepuasan Pelanggan (Y)

Sumber : Data diolah SPSS

Untuk menentukan nilai persamaan regresi linear bergandanya sebagai berikut :

$$
\mathrm{Y}=7,702+0,709 \mathrm{X}
$$

Dapat dijelaskan sebagai berikut :

a. Nilai konstanta intersep sebesar 7,702 menyatakan bahwa jika variabel Promosi (X), adalah nol meningkat I satuan, maka variabel Tingkat Penjualan Produk Beserta Peramalan Penjualannya (Y) akan meningkat sebesar 7,702 . 
b. Nilai koefisen regresi Promosi (X) terhadap Tingkat Penjualan Produk Beserta Peramalan Penjualannya (Y) adalah sebesar 0,709. Hal ini berarti jika Promosi (X) meningkat 1 satuan maka Kepuasan Pelanggan (Y) akan meningkat sebesar 0,709 dengan asumsi Promosi (X) dianggap konstan.

\section{Uji t}

Untuk mengetahui apakah masing-masing variabel penelitian ini diantaranya adalah Promosi (X) secara parsial mempunyai pengaruh bermakna terhadap variabel Tingkat Penjualan Produk Beserta Peramalan Penjualannya (Y) dilakukan pengujian $\mathrm{t}_{\text {hitung }}$ dan $\mathrm{t}_{\text {tabel }}$. Untuk Uji $t$ ini penulis melakukan dengan cara membandingkan antara $t_{\text {hitung }}$ dengan $t_{\text {tabel }}$ yaitu memiliki nilai masing-masing sebagai berikut

Tabel 8

Hasil Uji t (Hipotesis)

\begin{tabular}{|c|c|c|c|c|}
\hline Variabel & Nilai & $\begin{array}{c}\text { Standard } \\
\text { Error }\end{array}$ & $\mathbf{t}_{\text {hitung }}$ & $\mathbf{t}_{\text {tabel }}$ \\
\hline Promosi (X) & 0,709 & 0,058 & 12,316 & 1,665 \\
\hline
\end{tabular}

Sumber : Data diolah SPSS

Berdasarkan hasil uji hipotesis antara variabel Promosi (X) Terhadap Tingkat Penjualan Produk Beserta Peramalan Penjualannya (Y) diperoleh nilai $\mathrm{t}_{\text {hitung }}$ sebesar $=12,316>\mathrm{t}_{0,05(75)}=1,665$, maka $\mathrm{H}_{\mathrm{o}}$ ditolak dan $\mathrm{H}_{\mathrm{a}}$ diterima yang berarti mempunyai cukup bukti bahwa antara variabel Promosi (X) terhadap variabel Tingkat Penjualan Produk Beserta Peramalan Penjualannya (Y) ada pengaruh signifikan.

\section{KESIMPULAN DAN SARAN Kesimpulan}

Berdasarkan pada hasil analisa dan pembahasan penulis akan menarik suatu kesimpulan. Adapun kesimpulannya sebagai berikut :

a. Setelah dilakukan analisa regresi bahwa ternyata variabel Promosi dapat meningkatkan Tingkat Penjualan Produk Beserta Peramalan Penjualannya diperoleh nilai $\mathrm{Y}=7,702+0,709$ $\mathrm{X}$, ada pengaruh positif terhadap Tingkat Penjualan Produk Beserta Peramalan Penjualannya diperlukan pembuktian dengan dilakukannya uji hipotesis variabel Promosi terhadap variabel Tingkat Penjualan Produk Beserta Peramalan Penjualannya diperoleh nilai $\mathrm{t}_{\text {hitung }}$ sebesar $=12,316>$ nilai $\mathrm{t}_{\text {tabel }}$ pada ${ }_{(75)}$ sebesar $=1,665$, maka $\mathrm{H}_{\mathrm{o}}$ ditolak dan $\mathrm{H}_{\mathrm{a}}$ diterima yang berarti mempunyai bukti, bahwa antara variabel Promosi terhadap variabel Tingkat Penjualan Produk Beserta Peramalan Penjualannya terdapat pengaruh yang signifikan.

b. Berdasarkan hasil analisa dan uji hipotesisnya dinyatakan bahwa terdapat pengaruh positif antara variabel Promosi terhadap variabel Tingkat Penjualan Produk Beserta Peramalan Penjualannya diperoleh nilai sebesar 0,8187 sehingga dapat disimpulkan bahwa pengaruhnya sangat kuat atau nilai Koefisien determinasinya (KD) sebesar : 66,9\%.

\section{Saran}

Berdasarkan pada kesimpulan tersebut di atas, penulis akan memberikan saran yang diharapkan dapat berguna bagi sekolah. Adapun saran-saran sebagai berikut :

a. Pimpinan PT. Askotama Inti Nusantara hendaknya menjadikan Promosi sebagai ujung tombak dalam kegiatan pemasaran produk dan jasanya agar menjadi lebih baik hasil penjualannya, hal ini terlihat dari hasil analisa menghasilkan nilai analisa sudah sangat baik, dengan mengoptimalkan promosi hingga dapat memperbaiki tingkat Tingkat Penjualan Produk Beserta Peramalan Penjualannya cukup optimal dimasa yang akan datang yang tidak sedikit pesaing dari perusahaan sejenisnya.

b. Pimpinan PT. Askotama Inti Nusantara hendaknya terus memberikan tingkat Tingkat Penjualan Produk Beserta Peramalan Penjualannya agar dimasa yang akan datang lebih baik lagi tingkat Tingkat Penjualan Produk Beserta Peramalan Penjualannya sebagaimana yang diharapkan banyak pihak lebih maksimal guna memberikan tingkat kepuasan pada Pelanggannya dengan optimal.

c. Seluruh karyawan PT. Askotama Inti Nusantara hendaknya dapat meningkatkan kegiatan pemasaran dengan Promosi sehinga dimasa yang akan datang seluruh karyawan dapat bekerja optimal hingga akan terus meningkatkan Tingkat Penjualan Produk Beserta Peramalan Penjualannya dan sesuai dengan harapan pimpinan saat ini dan dimasa yang akan datang. 


\section{DAFTAR PUSTAKA}

Arikunto, Suharsimi, 2014., Prosedur Penelitian Suatu Pendekatan Praktek. Badan Penerbit Rineka Cipta. Jakarta.

Basu Swastha (2008, Manajemen Pemerinthan dalam Prespektif Pelayanan Publik, Badan Penerbit Mitra Wacana Media, Jakarta.

Daniel Hunt, V.2013, Managing for Quality: Integrating Quality and Business Strategy. Homewood, Ilinois: Business One Irwin.

Fandy. Tjiptono, 2009. Prinsip \& Dinamika Pemasaran. Edisi Pertama. Badan Penebit $\mathrm{J}$ \& J Learning. Yogyakarta.

Freddy Rangkuti, 2015, Teknik Mengukur dan Strategi Meningkatkan Kepuasan Pelangan”, Badan Penerbit PT Gramedia Pustaka Utama, Jakarta.

Hadari Nawawi, 2012. PromosiMenurut Islam, Badan Penerbit Gadjah Mada University press, Yogyakarta.

Hermawan Kartajaya. 2006. Hermawan Kartajaya on Marketing Mix seri 9 Elemen Marketing. Bandung: PT Mizan Pustaka.

Husein Umar, 2010. Riset Sumber Daya Manusia Dalam Organisasi, Badan Penerbit Rajawali Pers. Jakarta.

Juhaeri, 2011, Pengaruh Kualitas produk, harga dan promosi terhadap Tingkat penjualan.

J. Supranto, 2015. Metodologi Ramalan Kuantitatif untuk Perencanaan Ekonomi dan Bisnis, Badan Penerbit PT. Rineka Cipta. Jakarta.

Lesley Wiliam,"Manajemen Pemasaran-Studi Kasus Indonesia" Edisi 1, Penerbit Lembaga Manajemen PPM dan Penerbit P

Lupiyoadi, R. A. Hamdani. 2006. Manajemen Pemasaran Jasa, Edisi 2, Penerbit Salemba Empat, Jakarta.

Lupioyadi, Rambat, Konsumen dan Jasa, Badan Penerbit Salemba Empat, Jakarta. 2006.

Kotler, Philip., 2014. "Manajemen Pemasaran, Analisis, Perencanaan, Implementasi dan Pengendalian”, Alih Bahasa Jaka Wasana, Badan Penerbit PT. Gelora Antara Pratama, Jakarta.
Kotler, Philip, "Manajemen Pemasaran", Edisi 12 jilid 1, Penerbit PT Indeks Kelompok Gramedia, Jakarta, 2009

Mulia Nasution, 2012, Manajemen Pemasaran, Dasar Konsep dan Strategi, Penerbit CV. Rajawali Pers, Jakarta,

Parasurahman, Zeithaml dan Berry dalam Hans, 2009, Pelayanan Pelanggan yang Sempurna, Badan Penerbit Kunci Ilmu, Yogyakarta.

Saladin, Djaslim. 2007, "Intisari Pemasaran dan Unsur-unsur Pemasaran", Edisi 4, Penerbit Linda Karya, Bandung.

Sonny Harsono, 2010, Skala Pengukuran Variabelvariabel Penelitian, Badan Penerbit, ALFABETA, Bandung.

Simamora, H. 2007. "Manajemen Pemasaran Internasional", Edisi 2 Jilid 2, Penerbit Rineka Cipta, Jakarta.

Sofyan Assauri, 2014. Manajemen Pemasaran, Dasar, Konsep, Dan Strategi, Edisi Kedua, Badan Penerbit Rajawali, Jakarta,

Subiyanto, Ibnu. 2010. "Metodologi Penelitian Bisnis", Edisi 3, Penerbit Unit Penerbit dan Percetakan (UPP) Akademi Manajemen Perusahaan YKPN.

Sugiyono, 2016, Metode Penelitian Bisnis, Badan Penerbit ALFABETA. Bandung.

Sutisna, 2011, Manajemen Pemasaran dan Analisis Perilaku Konsumen, Badan Penerbit, CV. Intermedia Jakarta.

Tjahya.Supriatna, 2016, Manajemen Loyalitas, dan Sumberdaya Aparatur, Badan Penerbit. CV. Indra Prahasta, Bandung.

Tjiptono, F. Gregorius, C. Dadi, A.. 2008 "Pemasaran Strategik",Jilid 1, Penerbit CV. Andi Offset, Yogyakarta.

Utami, C.W, 2006, “Manajemen Ritel”, Jilid 1, Penerbit Salemba Empat, Jakarta. Yusuf, E.Z.

William J., Stanton, 2012., Fundamentalis Of Marketing”, Dikutip oleh Basu Swastha \& Irwan, "Manajemen Pemasaran Modern”, Penerbit Liberty Yogyakarta. 